\title{
Useful Parameters To Predict the Eventual Mental Outcome of Hypothyroid Children
}

\author{
JACQUELINE GLORIEUX, MANON DESJARDINS, JACQUES LETARTE, JEAN MORISSETTE, \\ AND JEAN $H$. DUSSAULT \\ The Quebec Network for Genetic Medicine, Centre Hospitalier de l'Université Laval, Ste-Foy, \\ Québec, Canada GIV $4 G 2$
}

\begin{abstract}
The Quebec Network for Genetic Medicine has followed the development of some 100 hypothyroid children treated by 1 month of age and evaluated at 18 months, 3 and 5 yr and the Griffiths Mental Development Scales, then at 7 and $9 \mathrm{yr}$ with the Wechsler Intelligence Scale for Children Revised. Results show that the children as a group reach scores within the normal range of the tests. However, a few patients have low scores at each evaluation. Previously, we showed a correlation between a low serum thyroxine concentration, or a relatively retarded bone maturation before treatment, and low mental scores. To better characterize the significance of this relationship we correlated these pretreatment factors and the Wechsler Intelligence Scale for Children Revised results of 43 subjects reaching the age of $7 \mathrm{yr}$. Again, the same correlation was observed. Calculating a predictive factor (low thyroxine, $<2 \mu \mathrm{g} / \mathrm{dl}$ and retarded bone surface, $<0.05 \mathrm{~cm}^{2}$ ) from data recorded before therapy initiation, 10 of 13 children were correctly predicted to have I.Q. values $<90$. The use of these parameters might permit early intervention, and allow specific guidance of the more affected subjects. ( $P e_{-}$ diatr Res 24: 6-8, 1988)
\end{abstract}

\section{Abbreviations}

$T_{4}$, thyroxine

$\mathrm{DQ}$, developmental quotient

$\mathrm{CH}$, congenital hypothyroidism

W.I.S.C.R., Wechsler Intelligence Scale for Children Revised

Ten years of follow-up of congenitally hypothyroid children detected by newborn screening programs have confirmed the effectiveness of early treatment in normalizing mental development (1). I.Q. values at 5-7 yr of age are in the normal range in most patients. However, significant differences between subjects and controls, or siblings, have been observed (2-6). The Quebec Network for Genetic Medicine screened 250 congenital hypothyroid patients between 1975 and 1985 , and 105 infants were recruited for a longitudinal study. All were French Canadian Caucasians, without any other known deficit or disease, coming from stable families, and they responded well to therapy. Description of biological (7) and psychological (3) characteristics of the group have already been reported showing a significant correlation between I.Q., a low serum $\mathrm{T}_{4}$ concentration and a delayed bone maturation (8-11). A careful assessment of individual

Received March 23, 1987; accepted February 25, 1988.

Correspondence and reprint requests Jacqueline Glorieux, Quebec Network of Genetic Medicine, Centre de Recherche Pédiatrique, Hôpital Ste-Justine, 3175, Côte Ste-Catherine, Montréal, Québec, Canada H3T iC5. scores allowed identification of a few children who scored consistently low throughout the evaluations. Herein, we examined pretreatment factors that might permit early detection of these subjects.

\section{PATIENTS AND METHODS}

Mental assessment was done using the Griffiths Mental Development Scales (12) at the age of 18 months and 3 and $5 \mathrm{yr}$. This test provides the global D.Q. and scales assessing locomotion, social development, hearing and speech, eye-hand coordination, performance, and depending the age of the patient, practical reasoning. It is an elaborate test well suited to determine possible differences within our group of patients. It is the only test covering child development from birth to the age of $7 \mathrm{yr}$. However, at the age of 7 and $9 \mathrm{yr}$ we worked with the W.I.S.C.R. (13) as recommended in the guidelines for Neonatal Screening Programs (14). Biochemical values of the patients have been reported (7), and treatment (mean age 32 days) followed the recommended dosage of replacement hormone $(8-10 \mu \mathrm{g} / \mathrm{kg} /$ day). The evolution of treatment was satisfactory but individual responses to therapy covered a wide spectrum (Table 1). The small number of subjects ( 17 at $5 \mathrm{yr}, 18$ at $7 \mathrm{yr}$ ) probably explain the fact that the first measures of $T_{4}(45$ days and $3,6,12$, and 18 months) never significantly correlated with the mental outcome, although the correlation coefficients between the $\mathrm{T}_{4}$ at 3 months and DQ at 5 and 7 are very close to the $5 \%$ level of significance ( 0.479 and 0.406 , respectively). Bone maturation was calculated by measuring the surface areas of the ossification centers of the knee using $\mathrm{x}$-ray carried out following the method described by one of us (15).

\section{RESULTS}

We reported that the mental development of the children considered as a group was within the normal range at each assessment. We assessed the effects of various clinical, biological, and radiological parameters possibly linked to the later performance of the patients. The presence or absence of thyroid tissue, or delay in the initiation of therapy, did not relate to mental status. Initial $\mathrm{T}_{4}$ and bone maturation were the best parameters explaining the patients developmental performance. Correlations of these parameters with intellectual assessment was always significant (Table 2). Taking both measures into consideration, we tried to develop a predictive index for eventual mental outcome. We arbitrarily defined a global score of 90 calculated with the W.I.S.C.R. at the age of $7 \mathrm{yr}$, as the superior limit of I.Q. for children with slow development, considering that data collected on 19 siblings from the original cohort gave a mean I.Q. of 106 (SD 16.7) with the same tests. Thirteen patients had scores under or equal to 90 and they were significantly different from the rest of the group only in their initial $\mathrm{T}_{4}$ values $(p<0.05)$ and bone 
Table 1. Thyroid function parameters in infants with congenital hypothyroidism detected by newborn screening and treated within 1 month of age

\begin{tabular}{|c|c|c|c|c|c|c|}
\hline \multirow[b]{2}{*}{$\begin{array}{c}\text { Age at } \\
\text { measurement }\end{array}$} & \multirow[b]{2}{*}{$n$} & \multicolumn{5}{|c|}{ Number of infants and test } \\
\hline & & $\begin{array}{c}\text { Serum } \mathrm{T}_{4} \\
(\mu \mathrm{g} / \mathrm{dl}) \\
\pm \mathrm{sem}\end{array}$ & $n$ & $\begin{array}{c}\mathrm{TSH}^{*} \\
(\mu \mathrm{U} / \mathrm{ml}) \\
\pm \mathrm{sem}\end{array}$ & $n$ & $\begin{array}{c}\mathrm{T}_{3} \dagger \\
(\mathrm{ng} / \mathrm{dl}) \\
\mathrm{m} \pm \text { sem }\end{array}$ \\
\hline Pretreatment & 43 & $1.4 \pm 0.2 \ddagger$ & 43 & $571 \pm 37$ & 33 & $74 \pm 12$ \\
\hline 45 days & 19 & $6.6 \pm 0.4$ & 13 & $31 \pm 14$ & 10 & $288 \pm 47$ \\
\hline $3 \mathrm{mo}$ & 18 & $11.8 \pm 1.5$ & 8 & $16 \pm 4.5$ & 6 & $155 \pm 13$ \\
\hline $6 \mathrm{mo}$ & 41 & $11.8 \pm 0.7$ & 39 & $17 \pm 3.4$ & 40 & $152 \pm 8$ \\
\hline $12 \mathrm{mo}$ & 43 & $12.3 \pm 0.8$ & 32 & $12 \pm 3.2$ & 42 & $160 \pm 7$ \\
\hline $18 \mathrm{mo}$ & 26 & $13.6 \pm 0.9$ & 25 & $11 \pm 3$ & 27 & $155 \pm 27$ \\
\hline
\end{tabular}

* Thyrotropin-stimulating hormone.

$\dagger$ Triiodothyronine.

$\ddagger$ Correlation with IQ at $7 \mathrm{yr}, p<0.05$ (mean $\pm \mathrm{SEM}$ ).

Table 2. Pretreatment parameters and mental outcome correlations in 43 infants with congenital hypothyroidism treated by 1 month of age

\begin{tabular}{|c|c|c|c|}
\hline \multirow{2}{*}{$\begin{array}{l}\text { Newborn } \\
\text { parameters }\end{array}$} & \multicolumn{3}{|c|}{$\begin{array}{c}\text { Correlations with intellectual } \\
\text { assessments }\end{array}$} \\
\hline & DQ 3 yr & DQ $5 \mathrm{yr}$ & IQ $7 \mathrm{yr}$ \\
\hline Plasma $T_{4}$ & $0.33^{*}$ & $0.36^{*}$ & $0.36 \dagger$ \\
\hline Bone surface & $0.51^{*}$ & $0.52^{*}$ & $0.40 \dagger$ \\
\hline
\end{tabular}

$* p<0.01$.

$\dagger p<0.05$.

surface measurement $(p<0.06)$. We then specified our risk criteria by selecting $\mathrm{T}_{4}$ values $<2 \mu \mathrm{g} / \mathrm{dl}$ (mean of the total group is $1.7 \mu \mathrm{g} / \mathrm{dl}$, SEM 0.8 ) and bone surfaces $<0.05 \mathrm{~cm}^{2}$ (taking into account the cumulated distribution of logarithmic data of the whole group). Applied to a total of 43 patients at the age of $7 \mathrm{yr}$ this index correctly identifies 10 of the 13 children having an I.Q. score $<90$ (sensitivity of measure $77 \%$ ). (Table 3 ). In other words, the prediction of a lower mental development score at the age of seven was accurate in only $63 \%$ of our sample. Those children had a mean I.Q. score of 81 . However, six children with borderline scores were also selected; their mean I.Q. was 95. However, the risk criteria correctly predicted an I.Q. $>90$ for 24 of the 30 children remaining (specificity of measure $80 \%$ ). The prediction of a higher mental score was accurate in $89 \%$ of our sample and the mean I.Q. of those patients was 105 (Table 3).

The effect of this discrimination factor on mental score at each assessment illustrates well the differences within our group of patients: the W.I.S.C.R. sub-test results were analysed by Student's $t$ test. The mean verbal score was 83 for the selected group versus 99 for the less affected children $(p<0.001)$; the nonverbal scores were 92 and $107(p<0.001)$ and the global I.Q. values 86 and $102(p<0.001)$, respectively. The same discrimination was evident in the scores of the 19 oldest patients evaluated at the age of 9 yr: the verbal scores were 88 for the selected group versus 105 for the less affected children $(p<0.003)$; the nonverbal scores were 96 and $114(p<0.002)$ and the global I.Q. values 91 and $109(p<0.001)$, respectively. At the age of $5 \mathrm{yr}$, the scores reached by the two groups of patients in the six scales of the Griffiths test were analysed by Student's $t$ test and showed important score differences. The locomotion was 81 for the selected group versus 106 for the less affected children $(p<$ $0.001)$; the respective social development scores were 96 and 121 $(p<0.001)$, the speech scores 94 and $112(p<0.003)$, coordination scores 89 and $107(p<0.001)$, the performance scores 89 and $105(p<0.01)$, the practical reasoning scores 78 and 89 $(p<0.005)$ and the global I.Q. values 88 and $106(p<0.001)$. On the whole, the results of mental assessment showed a wider difference (Table 4) in the mean scores of the described subgroups of hypothyroid children than the discrimination previously found between the whole group of patients and controls (3). The predictive value of the proposed index holds significantly through time (correlation between scores of the 43 children at the age of 18 months and 7 yr: $r=0.60, p<0.01$ ).

The two subgroups did not differ in terms of age when therapy started, initial thyroid hormone dosage, or, as far as could be assessed, compliance. They were similar in their biochemical parameters at the age of 45 days and $3,6,12$, and 18 months (Table 5).

Socially, the groups were different, having Hollingshead's scores of 54 versus $45(p<0.07)$. The more affected children came from less educated families. However, the correlation between I.Q. and Hollingshead's scores was much lower for the more affected children $(n=16, r=-0.139)$ than for the less affected patients $(n=27, r=-0.647)$. This difference is significant $(p<0.067)$, perhaps indicating that more affected patients do not benefit as much from the higher status of their parents because of specific physiological condition.

\section{DISCUSSION}

A relationship between the thyroidal status of $\mathrm{CH}$ patients at birth and their mental outcome has been suggested in several recent reports (17-19). Murphy et al. (17) showed that children who had a low $\mathrm{T}_{4}$ and triiodothyronine did significantly less well on the McCarthy general cognitive index at $3 \mathrm{yr}$, and noticed that children with very delayed bone age also did relatively poorly (17). This was suggested long ago by Wolter et al. (18) and more recently confirmed by Rovet et al. (19). The use of the combined measures of serum $\mathrm{T}_{4}$ and precise bone surface measure permit the selection of children who might benefit from psychological assessment. Their early identification would allow the physician to make a reasonable prediction of a lower range DQ outcome and permit early provision of specific support for optimal development. We would suggest that the parents be informed so that their cooperation can be maintained throughout childhood development; they might be more compliant with therapy and keep a positive attitude even if, as predicted, the performance of their child may not reach the level of his siblings or his peers.

Our results also emphasize the success of a decade of newborn

Table 3. Global WISCR IQ value at age of 7 yr for 43 infants with congenital hypothyroidism treated by 1 month of age

\begin{tabular}{lcc}
\hline & \multicolumn{2}{c}{$\begin{array}{c}\text { No. of children } \\
\text { with I.Q. }\end{array}$} \\
\cline { 2 - 3 } Newborn risk criteria & $<90$ & $>90$ \\
\hline $\begin{array}{l}\text { Bone surface }<0.05 \mathrm{~cm}^{2} \text { and } \mathrm{T}_{4} \\
\quad 2 \mu \mathrm{g} / \mathrm{dl}\end{array}$ & 10 & 6 \\
$\begin{array}{l}\text { Bone surface }>0.05 \mathrm{~cm}^{2} \text { and/or } \\
\quad \mathrm{T}_{4}>2 \mu \mathrm{g} / \mathrm{dl}\end{array}$ & 3 & 24 \\
Total & 13 & 30 \\
\hline
\end{tabular}

Table 4. Mental outcome in infants with congenital hypothyroidism relative to newborn risk criteria

\begin{tabular}{|c|c|c|c|c|c|c|}
\hline \multirow[b]{3}{*}{$\begin{array}{l}\text { Age }(\mathrm{yr}) \\
\text { in year }\end{array}$} & \multicolumn{6}{|c|}{$\mathrm{T}_{4}$ and bone surface measures } \\
\hline & \multicolumn{3}{|c|}{$\begin{array}{c}\mathrm{T}_{4}<2 \mu \mathrm{g} / \mathrm{dl} \text { and bone } \\
<0.05 \mathrm{~cm}^{2}\end{array}$} & \multicolumn{3}{|c|}{$\begin{array}{c}\mathrm{T}_{4}>2 \mu \mathrm{g} / \mathrm{dl} \text { and/or bone } \\
>0.05 \mathrm{~cm}^{2}\end{array}$} \\
\hline & $n$ & Mean IQ & $\begin{array}{c}\text { IQ } \\
\text { distribution }\end{array}$ & $n$ & Mean IQ & $\begin{array}{c}\text { IQ } \\
\text { distribution }\end{array}$ \\
\hline 3 & 17 & $91 \pm 4^{*}$ & $(61-120)$ & 40 & $103 \pm 2$ & $(81-140)$ \\
\hline 5 & 14 & $88 \pm 3 \dagger$ & $(60-109)$ & 30 & $104 \pm 2$ & $(84-125)$ \\
\hline 7 & 16 & $86 \pm 3+$ & $(49-98)$ & 27 & $102 \pm 2$ & $(75-128)$ \\
\hline
\end{tabular}

$* p<0.01(\mathrm{SEM})$.

$\dagger p<0.001$ (SEM). 
Table 5. Comparison of follow-up thyroid function test results in less affected and more affected infants as assessed by newborn risk criteria

\begin{tabular}{|c|c|c|c|c|c|c|c|c|c|c|c|c|}
\hline \multirow[b]{2}{*}{$\begin{array}{l}\text { Age at } \\
\text { testing }\end{array}$} & \multicolumn{6}{|c|}{ Less affected infants } & \multicolumn{6}{|c|}{ More affected infants } \\
\hline & $n$ & $\begin{array}{c}\mathrm{T}_{4} \\
(\mu \mathrm{g} / \mathrm{dl})\end{array}$ & $n$ & $\begin{array}{c}\mathrm{TSH}^{*} \\
(\mu \mathrm{U} / \mathrm{dl})\end{array}$ & $n$ & $\begin{array}{c}\mathrm{T}_{3} \dagger \\
(\mathrm{ng} / \mathrm{dl})\end{array}$ & $n$ & $\begin{array}{c}\mathrm{T}_{4} \\
(\mu \mathrm{g} / \mathrm{dl})\end{array}$ & $n$ & $\begin{array}{c}\text { TSH } \\
(\mu \mathrm{U} / \mathrm{ml})\end{array}$ & $n$ & $\begin{array}{c}\mathrm{T}_{3} \\
\text { (ng/dl) }\end{array}$ \\
\hline Pretreatment & 27 & $1.95 \pm 0.3$ & 27 & $565 \pm 52$ & 20 & $95 \pm 15$ & 16 & $0.50 \pm 0.1 \ddagger$ & 16 & $582 \pm 5$ & 13 & $43 \pm 15 \S$ \\
\hline 45 days & 11 & $6.8 \pm 0.7$ & 9 & $41 \pm 20$ & 6 & $260 \pm 63$ & 8 & $6.3 \pm 0.5$ & 4 & $9.3 \pm$ & 4 & $331 \pm 77$ \\
\hline $3 \mathrm{mo}$ & 12 & $12.2 \pm 1.6$ & 6 & $20 \pm 5$ & 5 & $162 \pm 14$ & 6 & $11.2 \pm 3$ & 2 & $6.5 \pm 0.8$ & 1 & 118 \\
\hline $6 \mathrm{mo}$ & 26 & $11.6 \pm 0.9$ & 24 & $19 \pm 4$ & 25 & $147 \pm 11$ & 15 & $12.1 \pm 1.2$ & 15 & $16 \pm 6$ & 15 & $161 \pm 9$ \\
\hline $12 \mathrm{mo}$ & 27 & $12.8 \pm 0.9$ & 27 & $9 \pm 2$ & 23 & $165 \pm 8$ & 16 & $11.4 \pm 1.4$ & 15 & $17 \pm 4.7$ & 9 & $148 \pm 16$ \\
\hline $18 \mathrm{mo}$ & 14 & $14.0 \pm 1.0$ & 15 & $16 \pm 5$ & 14 & $144 \pm 9$ & 12 & $13.2 \pm 1.6$ & 12 & $5 \pm 1.1$ & 11 & $170 \pm 11$ \\
\hline
\end{tabular}

${ }^{*} \mathrm{p}<0.001 ; * * \mathrm{p}<0.02$

* Thyrotropin stimulating hormone.

$\dagger$ Triiodothyronine.

$\ddagger p<0.001$ (mean $\pm \mathrm{SEM}$ ).

$\S p<0.02($ mean \pm SEM).

thyroid screening: the less affected children reached scores comparable to controls and siblings in most of the assessment, and there was no need for psychological follow-up. Even though the more affected patients might be slightly delayed in development, they reach better scores than those reported for nonscreened infants with $\mathrm{CH}$. Hulse (20) reported a mean I.Q. of 79.5 for 99 children with $\mathrm{CH}$ diagnosed before screening and evaluated with the W.I.S.C.R. Close follow-up will permit us to further substantiate our data and to assess the importance of specific guidance intervention.

\section{REFERENCES}

1. Rovet J, Glorieux J, Heyerdahl S 1987 Summary of presentations and discussion on the psychological follow-up of children identified by newborn screening. In: Therrell BL (ed) Advances in Neonatal Screening. Elsevier, Amsterdam, pp 71-75

2, Glorieux J, Dussault JH, Letarte J, Guyda H, Morissette J 1983 Preliminary results on the mental development of hypothyroid infants detected by the Quebec screening program. J Pediatr 102:19

3. Glorieux J, Dussault JH, Morissette J, Desjardins M, Letarte J, Guyda H 1985 Follow-up at ages 5 and 7 years on mental development in children with hypothyroidism detected by the Quebec screening program. J Pediatr 107:913-915

4. Rochiccioli P, Roge B, Alexandre F, Coll J, Dutau G, Enjaume C, Augier D 1983 Résultats du développement psychomoteur des hypothyroïdes dépistés à la naissance. Arch Fr Pediatr 40:537-541

5. Rovet JF, Westbrook DL, Erlich RM 1984 Neonatal thyroid deficiency: early temperamental and cognitive characteristics. J Am Acad Child Psychiatry 23:10

6. Glorieux J, La Vecchio F 1983 Psychological and neurological development in congenital hypothyroidism. In: Dussault $\mathrm{JH}$, Walker P (eds) Congenital Hypothyroidism. Marcel Dekker, New York, pp 411-430

7. Letarte J, Dussault JH, Guyda H, Fouron JC, Glorieux J 1981 Clinical and laboratory investigation of early detected hypothyroid infants. In: Collu R Ducharme JR, Guyda H (eds) Comprehensive Endocrinology. Raven Press, New York, pp 433-464

8. Glorieux $\mathbf{J} 1986$ Le développement mental des hypothyrö̈diens congénitaux le succès du dépistage. Med Sci 2:272-274

9. Dussault JH, Ruel J 1987 Thyroid hormones brain development. Annu Rev Physiol 49:321-334

10. Glorieux J, Desjardins M, Dussault JH, Letarte J, Morissette J 1987 Dix années de dépistage: étude longitudinale du développement mental des hypothyroidiens congénitaux. Arch Fr Pediatr 44:709-714

11. Glorieux J, Desjardins M, Dussault JH, Letarte J, Morissette J, Thibeault L 1987 Follow-up of congenitally hypothyroid children: delineation of a group at higher risk. In: Therell BL (ed) Advances in Neonatal Screening. Elsevier Amsterdam, pp 95-96

12. Griffiths R 1970 The Abilities of Young Children. London Child Development Research Center, Young and Sons, London

13. Wechsler D 1974 The Wechsler Intelligence Scale for Children rev ed. The Psychological Corporation, New York

14. 1980 Guidelines for neonatal thyroid screening programs. In: Burrow GN, Dussault JH (eds) Neonatal Thyroid Screening. Raven Press, New York, pp 307-310

15. Letarte J, Lafranchi S 1983 Clinical features of congenital hypothyroidism. In: Dussault JH, Walker P (eds) Congenital Hypothyroidism. Marcel Dekker, New York, pp 351-383

16. Hollingshead AB 1965 Two Factors Index of Social Position. Yale Station, New Haven, CT

17. Murphy G, Hulse JA, Jackson D, Tyrer P, Glossop J, Smith I, Grant D 1986 Early treated hypothyroidism: development at 3 years. Arch Dis Child 61:761-765

18. Wolter R, Noël P, De Cock P, Craen M, Ernould CH, Malvaux P, Verstraeten F, Simons J, Mertens S, Van Broeck N, Vanderschueren-Lodeweyckx M 1980 Neuropsychological study in treated thyroid dysgenesis. Acta Pediatr Scand Suppl 277:41-46

19. Rovet J, Erlich R, Sorbara D 1987 Intellectual outcome in children with fetal hypothyroidism. J Pediatr 110:700-704

20. Hulse JA 1984 Outcome for congenital hypothyroidism. Arch Dis Child 59:2023 